\title{
DNA Recombination Process
}

National Cancer Institute

\section{Source}

National Cancer Institute. DNA Recombination Process. NCI Thesaurus. Code C17082.

Any type of DNA sequence rearrangement involving possible exchange and frequent loss

of segments of DNA by either homologous recombination or non-homologous endjoining of broken DNA strands. Recombination is involved in assorting genes during reproduction, in repairing broken DNA, and in maintaining cell viability at the expense of long-term genomic stability. 